\title{
Editorial
}

\section{Outlining conflicts that can occur between legislation that protects differing forms of cultural heritage in the UK}

Journal of Building Appraisal (2009) 4, 143-147. doi:10.1057/jba.2008.43

\begin{abstract}
Where nationally important archaeological remains, whether scheduled or not, and their settings are affected by development, there should be a presumption in favour of their physical preservation. (Planning Policy Guidance Document 16 (PPG 16), Archaeology and Planning, 1990)
\end{abstract}

The above quote taken from PPG16, while quite dogmatic in its directive, would seem quite fair, because as it also states:

Archaeological remains should be seen as a finite, and non-renewable resource, in many cases highly fragile and vulnerable to damage and destruction.

Few could argue with this sentiment, but what if the development proposed includes essential maintenance work to a listed building, also a finite and non-renewable resource, or is developmentally essential to the future and potential survival of such a listed building? Should presumption not favour the building in these cases where the survival of a building is protected by a statute that insists its owners keep it in good repair? This editorial does not seek to provide definitive answers, as such answers are not possible. Nor does it take the part of either built heritage or archaeology camps, but rather cites from a practicing building surveyor's perspective a perceived conflict that any surveyor or planner might encounter when advising owners of certain types of listed buildings, such as churches and buildings located in historic locations, such as York, Lincoln, Nottingham, Canterbury and so on. As PPG16 cites, in 1990, there were 600000 recorded archaeological sites, of which 13000 had special protection as scheduled ancient monuments. Also as per PPG15, Planning and the Historic Environment (1994), there are similar numbers of listed buildings, with similar numbers singled out for special levels of protection. The sheer volume of potential archaeology and the number of buildings deemed worthy of statutory protection make it highly likely that a professional involved in a development or major repairs contract would need to be looking at both PPG16 and PPG15 to plot a recommended course of action that would not fall foul of the local planning department, and should be guided by both these documents. Owing to the complexity of the issue, the skills of a planning specialist to support the technical input of the surveyor would eventually be required.

It might be advantageous to establish what constitutes archaeology. Is it the discovery of buried prehistoric remains or the plucking from the ground of the urn full of Roman gold coins? Unfortunately, for the construction team this definition is not so clear. An indication that archaeology may exist is, according to PPG16, sufficient for archaeology 
to be presumed, and archaeology is additionally cited as covering a 4000-year slice of history, with some twentieth century remains constituting archaeology. In cities such as Nottingham, which is honeycombed with historic caves, and cities like York, where layers of archaeology from Roman, Viking and Medieval times fill the ground throughout city centre, such an indication is always likely exist. Given the rise in importance of industrial archaeology following the demise of Britain's heavy industries, other towns may also become certainties for the presumption of archaeology beneath any of their sites.

What does an indication of the presence of archaeology mean to proposed works to the incumbent listed building? This needs to be looked at in two stages: (i) How might an indication that archaeology might exist effect the terms of any planning permissions granted? and (ii) How might it impact upon the project itself in terms of time, methodology and costs? This investigation is undertaken with reference to PPG16; however, the nature of planning in the United Kingdom does not necessarily dictate that every planning authority will take this guidance as firm rules.

PPG16 advocates changes in design to remove a structure's footprint away from the archaeological site, so that any artefacts and remains can be preserved in situ. Clearly, as design is undertaken at an early stage of the development or remediation process and can often be expensive to alter, the potential presence of archaeological items needs to be established and factored into the design at an early stage. PPG 16 (Section 19) advocates early consultation between the development team and the county archaeologist, with early English Heritage involvement cited as being a wise move. It would be hoped that following these early discussions and with some preliminary archaeological investigations, it might be established whether the possible presence of archaeology would be a major factor in this project's undertaking.

Should the potential for an archaeological presence be established, the developer would be required by the planning authority at his or her own expense to arrange for field archaeological investigation of the site, before planning permission is considered. This would delay the project considerably and where the work involves remediation of an existing building could add to the cost by the need to provide additional temporary support equipment. PPG16 states that no local authority can trade funding for archaeological investigation for future planning permission, and no developer can expect payment for extensive investigation to be a ticket for granted planning permission. This effectively means that a developer could expend monies investigating a site for archaeological remains, could suffer the penalties of having a redundant site and at the end of the process could find that the quality of the archaeology that was found following their own funded dig leaves them without the planning permissions required to continue.

The above situation could be avoided by gaining the required planning permission subject to the negative condition that no development takes place until agreed levels of archaeological investigation have been concluded. Changes in design to protect remains, and the potential to declare the site a Scheduled Ancient Monument, thus releasing much more protective legislation, would still remain a threat to the project, however. It can clearly be established that the early consultation between archaeologists and developers is a very wise avocation of PG16, as the presence of significant finds may make walking away from the project the economically sensible option.

There is a further danger to the developer from archaeology, and that is the discovery of unforeseen and significant artefacts during the excavation and demolition phases. This eventuality could see the site declared a scheduled ancient monument and work stopped pending scheduled ancient monument consent that may never be granted. Only a 
specialist insurance policy taken out before work commences could afford relief, should this scenario occur.

As can be seen, the potential for archaeological finds can create delays and additional costs, and discovery of significant archaeological evidence can prevent any work from occurring or can increase the design requirements significantly. As was originally supposed, the most likely place to find archaeology is within the curt ledge or even beneath a historic building. This places structural remediation work and often-essential development work to historic buildings and sites under great threat of archaeologically driven expense and delay. This would conflict with the terms of listed building legislation, which obligate the owner to keep said building in repair. It also conflicts with PPG15 Planning Policy Guidance, Planning and the Historic Environment, which cites putting historic buildings to a practical economic purpose as a valuable conservation tool. Under current legislation, owners of a failing historic building can be served with a repairs notice requiring them to undertake urgent work to their property, or can even have their property compulsorily purchased for peppercorn monies. Although there is no suggestion that the latter would happen while repairs are held up because of archaeological investigation, it evidences the importance that current and enforceable legislation places on maintaining listed buildings. Thus, not for the only time do the rules affecting specific areas of built environment work create conflict and require precise and inspired professional advise from planning and building surveyors.

It is not just conservation regulation governing built and archaeological heritage that conflicts. An example of multiple protection of the same site is Lincoln Castle Prison. Lincoln Castle is a fine example of nineteenth-century prison architecture, and the last surviving example of the solitary prison system, with a unique solitary worship chapel, and many original prison features remaining (Figures 1-3). The long drop system of execution by hanging was invented here. It is protected by grade 2 star listed status, which obligates its owners, Lincoln local authority, to keep it maintained. It does, however, sit

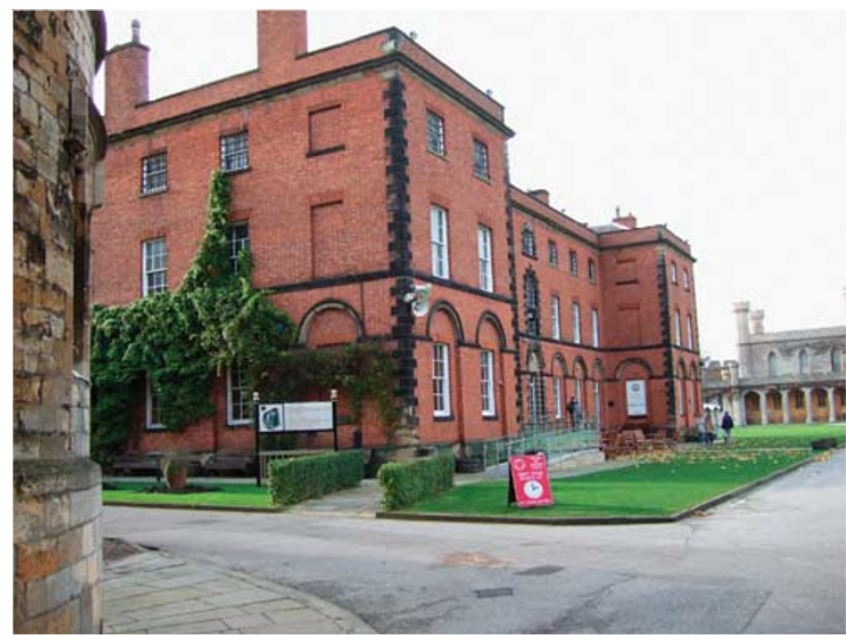

Figure I: Lincoln Castle Prison is a grade 2* listed building located within the Grade I Lincoln Castle and forming part of the cortège of the grade I Lincoln Cathedral. Situated within the area of Scheduled Ancient Monument status, and in a Conservation Area, it is additionally close to statutorily protected trees. The replacement of a decaying disabled ramp with the one present in the illustration took over 2 years for permissions to be granted. This building badly needs a proper use; however, it sits upon the old underground transportation cells and centuries of historically significant activity. 


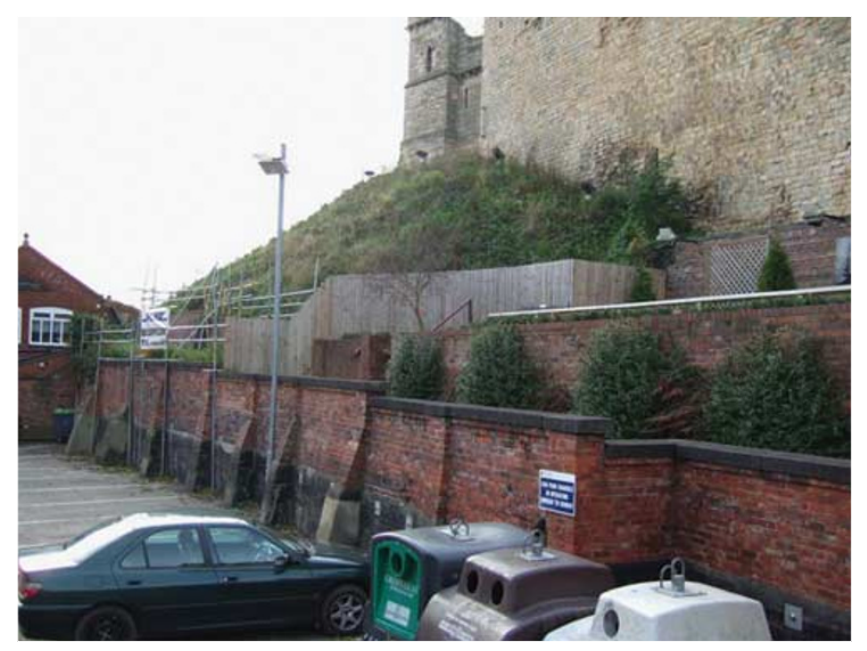

Figure 2: Repairs required on Victorian retaining walls to the castle earthworks, which impact upon the medieval walls and archaeology surrounding said walls, have been considerably delayed. The castle walls have a history of sudden collapse.

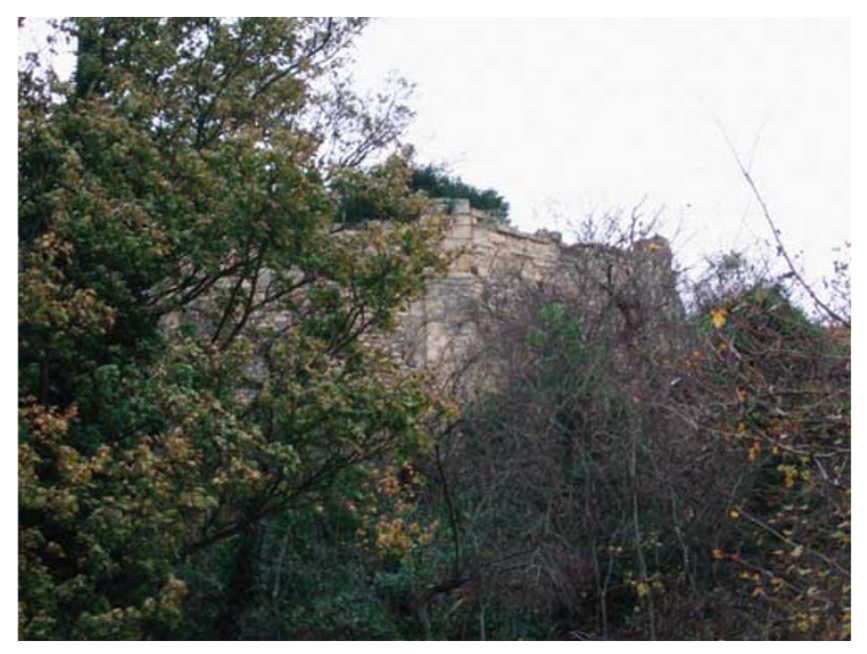

Figure 3: The Lucy Tower, the earliest part of the castle, is suffering structurally. Unfortunately, within the soil that fills its core lie the remains of those prisoners from Lincoln Castle Prison who were executed, and a millennium of potential archaeology.

within the confines of the grade 1 listed Lincoln Castle and inside the curt ledge of the grade 1 listed Lincoln Cathedral. The whole area has been designated as a Conservation Area and also a Scheduled Ancient Monument. The approach to the prison is lined by trees that are statutorily protected by Tree Preservation Orders. As the keeper of the Castle stated, the building only needs a colony of bats to take residence for the building to acquire the full set of possible conservation-based restrictions.

The story does occasionally have a happy ending. Essential repairs to the medieval foundations of York Minster, a very important grade 1 listed building, discovered the remains of a Roman civic building under the failing tower. Creative engineering not only secured the structure of this great building, but also afforded public viewing of the Roman 
remains in situ, for which the Minster can generate additional income. In that same ancient city, the Jorvic Centre opened upon the site of Viking remains on the site of a proposed shopping centre. This is now a very popular and lucrative tourist venue located beneath the shopping centre. Over 800 of the excavated artefacts remain in the centre and in the 21 years since it opened, an average of 667000 people have visited every year. On a smaller scale, public admission to the cave dwellings and troglodyte commercial activities over which the Broadmarsh shopping centre in Nottingham bridges provides a valuable and lucrative insight into Nottingham's past.

To summarise, both historic buildings and archaeological sites can be protected by planning and other legal constraints. As one of the favourite spots to discover archaeology is beneath or immediately around a historic building, there is the potential for conflict when structural repairs to the building or economically required development threatens potential buried archaeology. Both forms of historic heritage can be protected by direct statute and the implementation of planning restriction driven by planning guidance documents. These are the 'Listed Building Regulations and PPG15' for buildings and 'Scheduled Ancient Monument status and PPG16' for archaeology. Steering a rehabilitation or development project through these conflicts is just one of the events that a modern UK surveyor is likely to meet in his or her daily work.

Simon Mclean Managing Editor 